\title{
CASPIAN SEA MATHEMATICAL MODEL OF FLUID DYNAMICS CONSIDERING THE PRESENCE OF ICE ON ITS SURFACE*
}

\author{
A.L. Leontyev ${ }^{1}$, M.I. Chumak ${ }^{2}$ \\ ${ }^{1}$ Southern Federal University, Rostov-on-Don, Russia \\ ${ }^{2}$ Don State Technical University, Rostov-on-Don, Russia
}

\leontyev_anton@mail.ru,chumaaak1908@gmail.com

\begin{abstract}
This article is devoted to the development and research of a mathematical model of water fluid dynamics with variable depth. This model describes the water flow movement, the thermodynamics of ice formation and melting, considers the Coriolis force, horizontal and vertical turbulence of the water environment, the complex geometry of the coastline and bottom, friction on the bottom and wind currents, evaporation, wind speed, and atmospheric density, and the deviation of the pressure field value from the hydrostatic approximation. The article describes the influence of the spatial distribution of temperature, salinity, ionic composition, and hydrostatic pressure on the processes of ice cover formation. The Caspian Sea-was chosen as the object of the simulation. The changes in the temperature and salinity distributions measured by the electrical conductivity of the water, considering the ionic composition of the Caspian Sea waters over a long-term period, are used as input data. Modeling the movement of water flow will allow you to respond to man-made threats in an accelerated time mode. The models of hydrodynamics presented in this paper can be adapted for other reservoirs using the appropriate geoinformation systems.
\end{abstract}

Keywords: Caspian Sea, mathematical modeling, water flow velocity field, ice formation, ionic composition, temperature

Introduction. To ensure the main marine sectors of the country's economy, information on the hydrometeorological situation in the waters of the Russian Federation is needed. At the same time, full-scale observation of the main fluid dynamics indicators in the open sea is difficult and costly. The information received from coastal hydrometeorological stations is not sufficient for use in the study and modeling of the hydrodynamics of reservoirs. Data from coastal stations only allow us to summarize the main indicators.

This problem was identified during the development of natural resources of the seas, namely shelf zones. Successful development of oil and gas resources requires the use of technologies and methods for determining the main hydrometeorological parameters, such as sea level, wind speed and current velocity, density, temperature and salinity.

As part of the study of this topic, it was found that, despite numerous studies of the hydrodynamics of the seas and oceans, a number of poorly studied factors remain [2-4]. In addition, part of the research is based on a significant simplification of physical processes and idealization of

\footnotetext{
* The reported study was funded by RFBR according to the research project № 19-31-51017.
} 
the computational domain, which in turn leads to low accuracy of models and the lack of the possibility of their real application.

To minimize idealistic simplifications and increase the efficiency of the process of developing a mathematical model and modeling in general, a reservoir was chosen for the study - the Caspian Sea, which is a sea-lake by geographical location. The Caspian Sea is a closed body of water with a complex geometry of the coastline and bottom. Fig. 1 shows the conditional division of the reservoir into the Northern, Middle and Southern Caspian, along the Mangyshlak and Absheron rapids, respectively. The Northern Caspian is shallow, the Middle Caspian is deep - water (Derbent Depression), the Southern Caspian is deep-water (South Caspian Depression). The maximum depths reach $25 \mathrm{~m}, 800 \mathrm{~m}$ and $1025 \mathrm{~m}$ for the Northern, Middle and Southern Caspian, respectively.

The sea is located in three climatic zones, which allows for extensive research on the influence of climate on the dynamics of marine systems. Thus, in the northern part of the reservoir, the continental climate prevails, in the middle - moderate and subtropical in the southern part. Due to the closeness of the reservoir, special attention should be paid to the water balance formed by river runoff, evaporation, precipitation and groundwater inflow. Changes in the components that make up the water balance are reflected at the sea level. Over the past hundred years, the level of the Caspian Sea relative to the World Ocean has changed from $-26 \mathrm{~m}$, to a minimum level of $-29 \mathrm{~m}$. The maximum rise in sea level per year corresponds to $30 \mathrm{~cm}$, which is accompanied by overtaking phenomena and a significant change in the sea surface area. With such a change in sea level, the coastline shifts by tens of kilometers, which is especially noticeable in the shallow Northern Caspian Sea. It also has a strong effect on the ionic composition of water, that is, on the salinity and density of water, especially near the Kara-Bogaz-Gol Bay.

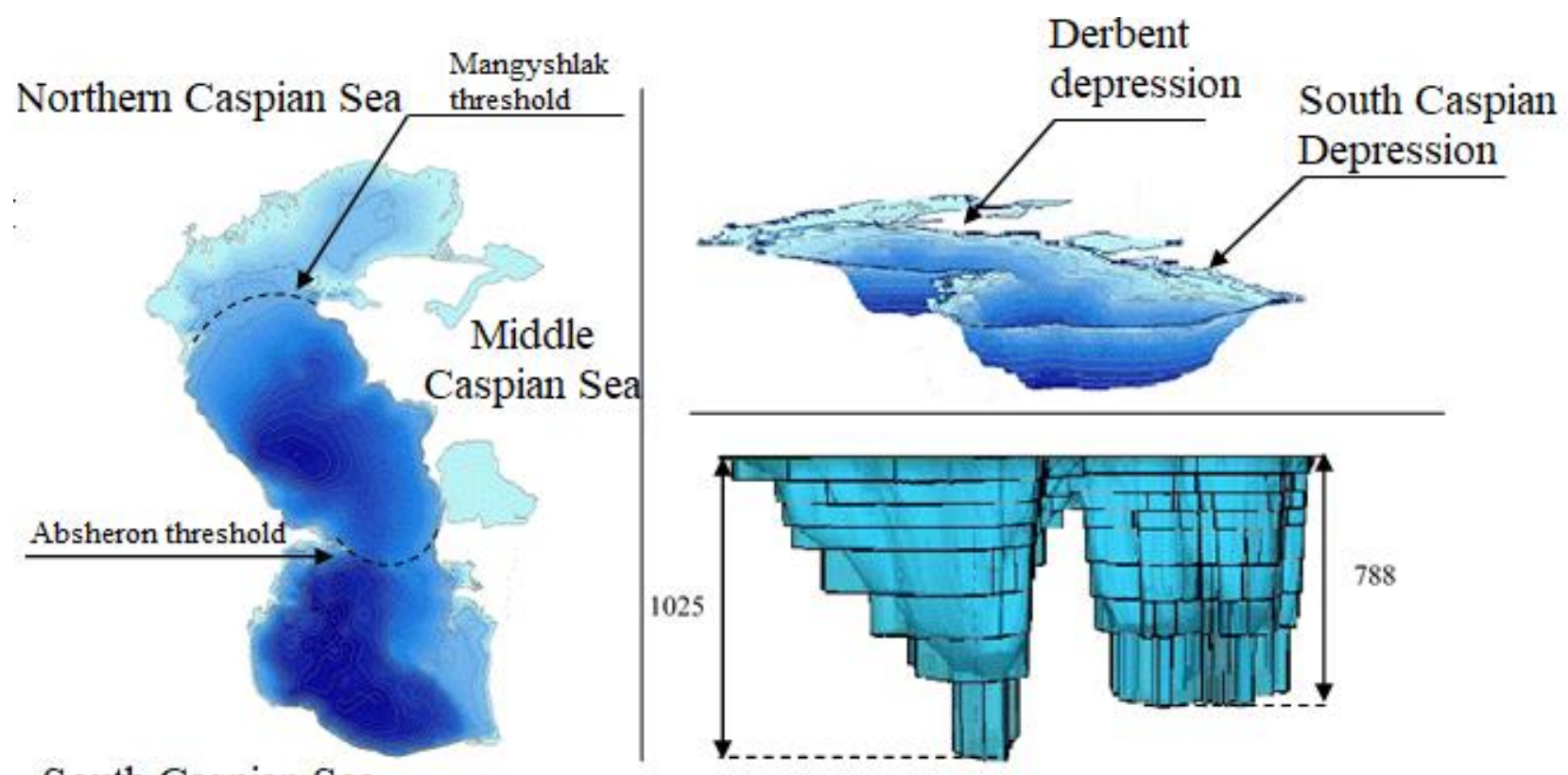

South Caspian Sea

Fig. 1. Caspian Sea bathymetry 
Problem statement. The Navier-Stokes and continuity equations are used to describe the dynamics of a sea with a lateral surface $\sum$, variable depth $H$ in the Cartesian coordinate system, with the $O z$ axis pointing vertically down, the $O y$ axis pointing north, and the $O x$ axis pointing east [5]:

$$
\begin{gathered}
u_{t}^{\prime}+u u_{x}^{\prime}+v u_{y}^{\prime}+w u_{z}^{\prime}=-\frac{p_{x}^{\prime}}{\rho}+\left(\mu u_{x}^{\prime}\right)_{x}^{\prime}+\left(\mu u_{y}^{\prime}\right)_{y}^{\prime}+\left(v u_{z}^{\prime}\right)_{z}^{\prime}+2 \Omega(v \sin \Theta-w \cos \Theta), \\
v_{t}^{\prime}+u v_{x}^{\prime}+v v_{y}^{\prime}+w v_{z}^{\prime}=-\frac{p_{y}^{\prime}}{\rho}+\left(\mu v_{x}^{\prime}\right)_{x}^{\prime}+\left(\mu v_{y}^{\prime}\right)_{y}^{\prime}+\left(v v_{z}^{\prime}\right)_{z}^{\prime}+2 \Omega u \sin \Theta, \\
w_{t}^{\prime}+u w_{x}^{\prime}+v w_{y}^{\prime}+w w_{z}^{\prime}=-\frac{p_{z}^{\prime}}{\rho}+\left(\mu w_{x}^{\prime}\right)_{x}^{\prime}+\left(\mu w_{y}^{\prime}\right)_{y}^{\prime}+\left(v w_{z}^{\prime}\right)_{z}^{\prime}+2 \Omega u \cos \Theta+g\left(\frac{\rho_{0}}{\rho}-1\right), \\
\rho_{t}^{\prime}+(u \rho)_{x}^{\prime}+(v \rho)_{y}^{\prime}+(w \rho)_{z}^{\prime}=0,
\end{gathered}
$$

where, $\mathbf{u}=\{u, v, w\}$ are the components of the flow velocity vector; $p$ is the pressure; $\rho$ is the density of sea water; $\Omega$ is the angular velocity of the Earth's rotation; $\Theta$ is the angle between the vertical and angular velocity; $\mu, v$ are the horizontal and vertical components of the turbulence coefficient.

Also, boundary and initial conditions have been added to the system (1) - (4):

- entrance (river mouths): $\mathbf{u}=\mathbf{u}_{0}, \rho_{\mathbf{n}}^{\prime}=0$,

- lateral surface (shore and bottom): $\rho_{v} \mu\left(\mathbf{u}_{\tau}\right)_{\mathbf{n}}^{\prime}=-\boldsymbol{\tau}, \mathbf{u}_{\mathbf{n}}=0, p_{\mathbf{n}}^{\prime}=0$,

- upper bound: $\rho \mu\left(\mathbf{u}_{\boldsymbol{\tau}}\right)_{\mathbf{n}}^{\prime}=-\boldsymbol{\tau}, w=-\omega-p_{t}^{\prime} /(\rho g), p_{\mathbf{n}}^{\prime}=0$,

- drain: $p_{\mathbf{n}}^{\prime}=0, \mathbf{u}_{\mathbf{n}}^{\prime}=0$,

where $\omega$ is the evaporation rate of the liquid; $\boldsymbol{\tau}$ is the tangent stress vector; $\mathbf{u}_{\mathbf{n}}, \mathbf{u}_{\boldsymbol{\tau}}$ are the normal and tangential components of the velocity vector of the water flow; $\rho_{v}$ is the density of the suspension.

The vector of tangential stresses for a free surface has the form: $\boldsymbol{\tau}=\rho_{a} C d_{s}|\mathbf{w}| \mathbf{w}, \mathbf{w}$ is the vector of wind speed relative to water, $\rho_{a}$ is the density of the atmosphere, $C d_{s}$ is the dimensionless surface coefficient of resistance depending on the wind speed.

The vector of tangential stresses in the case of a bottom surface has the form: $\boldsymbol{\tau}=\rho C d_{b}|\mathbf{u}| \mathbf{u}$, $C d_{b}=\left(g k^{2}\right) / h^{1 / 3}$, where $k$ is the Gokler-Manning coefficient; $h=H+\eta$ is the total depth of the reservoir, [m]; $H$ is the depth of the undisturbed liquid, [m]; $\eta$ is the position of the free surface relative to the geoid (sea level), [m].

The calculation of the density of seawater was carried out using the equation of state of seawater in 1980 [link to US-80]:

$$
\begin{gathered}
\rho=\rho_{0}+800.969062 \cdot 10^{-4}+588.194023 \cdot 10^{-4} T+ \\
\quad+797.018644 \cdot 10^{-3} S-811.465413 \cdot 10^{-5} T^{2}- \\
\quad-325.310441 \cdot 10^{-5} T S+131.710842 \cdot 10^{-6} S^{2}+ \\
+476.600414 \cdot 10^{-7} T^{3}+389.187483 \cdot 10^{-7} T^{2} S+ \\
\quad+287.971530 \cdot 10^{-8} T S^{2}-611.831499 \cdot 10^{-10} S^{3}
\end{gathered}
$$

where $\beta$ is the coefficient given in specialized oceanological tables, reflecting the dependence of density changes on temperature changes; $k(T, S, p)$ is the average modulus of elasticity; $\mathrm{T}$ is the water temperature; $\mathrm{S}$ is the salinity of water; $\mathrm{p}$ is the hydrostatic pressure. 
Due to the fact that the linear equation of the density of seawater gives extremely rough results and can significantly reduce the accuracy of the developed model, the model described earlier will use the equation of the state of seawater in 1980, approved by UNESCO.

To expand the range of use and increase the versatility of the hydrodynamic model, it is proposed to use bulk formulas that connect the heat flow from water to ice with the temperature contrast on the lower surface of the ice and the speed of ice drift. In an open water space, the heat flow is described by the formula

$$
\begin{gathered}
Q_{O W}=Q_{S H}+Q_{L H}+k Q_{S W}+Q_{L W}, \\
Q_{L H}=\rho_{A} q_{E} C_{D}\left(E_{0}+|\boldsymbol{W}|\right)\left(Q_{A}-Q_{\max }\right), Q_{S H}=\rho_{A} c_{A} C_{D}\left(E_{0}+|\boldsymbol{W}|\right)\left(T_{A}-T\right), \\
Q_{S W}=S W_{D W}\left(1-\alpha_{W}\right), Q_{L W}=L W_{D W} E_{W}-E_{W} \sigma_{S B} T^{4},
\end{gathered}
$$

where $Q_{S H}$ is the flow of explicit heat; $Q_{L H}$ is the flow of latent heat; $Q_{S W}$ is the balance of shortwave radiation; $Q_{L W}$ is the balance of long - wave radiation; $\rho_{A}$ is the density of air; $c_{A}$ is the heat capacity of air; $q_{E}$ is the specific heat of vapor formation; $Q_{\max }=k_{1} e /\left(P_{A}-0,378 e\right)$ is the humidity of saturated steam as a function of temperature and pressure; $e=10^{\frac{k_{2}+k_{3} T}{1+k_{4} T}+2}$ is the saturated vapor pressure; $T$ is the water surface temperature; $\boldsymbol{W}$ is the wind velocity vector relative to the ocean surface; $C_{D}$ is the coefficient depending on the surface properties; $E_{0}$ is a parameter characterizing the heat flow for windless weather; $\alpha_{W}$ is the water reflection coefficient; $E_{W}$ is the coefficient characterizing the ability to emit water; $\sigma_{S B}$ is the Stefan-Boltzmann constant; $k=0,6$ is the coefficient reflecting part of the short-wave radiation acting on the water surface.

To calculate the heat flow under the ice surface, the following ratio was used:

$$
Q_{O I}=-\rho_{0} c_{w} C_{b}\left(h_{i}\right)\left(T-T_{F}\right)+Q_{S W I},
$$

where $h_{i}$ is the thickness of the ice; $c_{w}$ is the heat capacity of the water; $Q_{S W I}$ is the part of the shortwave radiation penetrating under the ice in the absence of snow cover on it; the freezing temperature of the water $T_{F}$ at salinity $S$ and atmospheric pressure $p_{a}$ :

$$
T_{F}=-k_{5} S+k_{6} \cdot 10^{-3} S^{3 / 2}-k_{7} \cdot 10^{-4} S^{2}-k_{8} \cdot 10^{-3} p_{a} ;
$$

where $k_{i}, i=\overline{1,8}$ are constant coefficients; $C_{b}$ is a dimensionless coefficient depending on the thickness of the ice:

$$
C_{b}= \begin{cases}1,26 \cdot 10^{-2} W_{*} \sqrt{h_{i}}, & h_{i}<3 \\ 7,27 \cdot 10^{-3} W_{*}, & h_{i} \geq 3\end{cases}
$$

The total normalized heat flow is determined by the expression:

$$
q_{0}=\frac{1}{c_{W} \rho_{0}}\left(A_{0} Q_{O W}+\left(1-A_{0}\right) Q_{O I}\right)+\gamma_{\theta}\left(\theta_{o b s}-\theta\right),
$$

where $A_{0}$ is the sea surface area not occupied by ice; $\theta_{o b s}$ is the model temperature values; $\gamma_{\theta}$ is the coefficient that determines the negative feedbacks.

To simulate the process of salt transport in the Caspian Sea, evaporation from the latent heat flow is calculated:

$$
E=\frac{Q_{L H}}{q_{E} \rho_{0}}
$$


The boundary condition for the salinity flow in the sea, considering the change in the mass of ice and snow, is determined by the formula:

$$
Q_{s}=\left(S-S_{i}\right) \frac{1}{\rho_{0}} \frac{\partial m_{i}}{\partial t}+S \min \left(0, \frac{1}{\rho_{w}} \frac{\partial m_{s}}{\partial t}\right)-S P R_{A} \Phi\left(T_{A}, A_{0}\right)+S E A_{0}+\gamma_{S}\left(S_{o b s}-S\right),
$$

where $S_{i}$ is the average salinity of ice; $m_{i}, m_{s}$ is the mass of ice and snow; $P R_{A}$ is precipitation; $E$ is evaporation; $S_{o b s}$ is the model temperature values; $\gamma_{S}$ is the coefficient determining negative feedbacks; $\Phi$ is the dependence of air temperature on water not occupied by ice:

$$
\Phi\left(T_{A}, A_{0}\right)=\left\{\begin{array}{c}
1, T_{A} \geq 5^{\circ} \mathrm{C} ; \\
A_{0}+\frac{\left(1-A_{0}\right)\left(T_{A}+5\right)}{10},-5^{\circ} \mathrm{C}<T_{A}<5^{\circ} \mathrm{C} ; \\
A_{0}, T_{A} \leq-5^{\circ} \mathrm{C} .
\end{array}\right.
$$

Conclusion. The described model considers the dependence of heat fluxes on the thickness of ice in the case of thin annual ice and assumes that the salinity flow changes with changes in the mass of snow and as a result of melting ice under the snow. The nature of precipitation is considered, determined by the air temperature at an altitude of 0 to 2 meters above the surface of the reservoir.

The application of this observation model together with the system of equations of hydrodynamics of the sea will allow us to build an all-season mathematical model that can be used in shipping and oil production, as well as in predicting the consequences of man-made disasters, their impact on the development of the biohydrocenosis of the reservoir.

To model hydrophysical processes, data obtained from the database of the interdepartmental information system for access to the resources of marine information systems and integrated information support for marine activities (ESIMO), as well as from the Atlas of Climate Change in Large Marine Ecosystems of the Northern Hemisphere were used [1].

\section{References}

1. Matishov, G., Dashkevich, L. and Kulygin, V. Atlases of oceanographic observations as the tool of climatic analysis. 6-th European Congress on Regional Geoscientific Cartography and Information Systems Earth and Man EUREGEO (Munchen, June 9 - 12, 2009) Proceedings Volume II Printed by Landesamt fur Vermessung und Geoinformation, Munchen. pp. 105-107.

2. Dyakonov G.S., Ibrayev R.A. high-resolution data on mesoscale dynamics of the Caspian Sea upper layer, obtained in a numerical reconstruction // Data in Brief. 2020. V. 30. P. 105368.

3. Golshan M., N. Colombani N., Mastrocicco M. Assessing Aquifer Salinization with Multiple Techniques along the Southern Caspian Sea Shore // Water. 2018. No. 10. P. 348.

4. Marchuk G.I., Paton B.E. The Black Sea as a simulation ocean model // Russian Journal of Numerical Analysis and Mathematical Modelling. 2012. V. 27. No. 1. P. 1-4.

5. Sukhinov A.I., Chistyakov A.E., Leontyev A.L., Nikitina A.V., Filina A.A. Mathematical modeling of hydrophysical processes for water with complex bottom geometry // Journal of Physics: Conference Series. Applied Mathematics, Computational Science and Mechanics: Current Problems. 2020. P. 012083. 


\section{Authors:}

Anton Leontiev, Southern Federal University, (Bolshaya Sadovaya Str., 105/42, Rostov-on-Don, Russia),postgraduate student, leontyev_anton@mail.ru, ORCID: 0000-0002-0608-4343

Margarita Chumak, Don State Technical University Don State Technical University, (Gagarin square, 1, Rostov-on-Don, Russia), master's student, chumaaak1908@gmail.com 


\title{
МАТЕМАТИЧЕСКАЯ МОДЕЛЬ ГИДРОДИНАМИКИ КАСПИЙСКОГО МОРЯ С УЧЕТОМ ЛЬДА НА ЕГО ПОВЕРХНОСТИ*
}

\author{
А.Л. Леонтьев ${ }^{1}$, М.И. Чумак ${ }^{2}$ \\ ${ }^{1}$ Южный федеральный университет, Ростов-на-Дону, Российская Федерация \\ 2 Донской государственный технический университет, Ростов-на-Дону, Российская \\ Федерация
}

leontyev_anton@mail.ru,chumaaak1908@gmail.com

Работа посвящена разработке и исследованию математической модели гидродинамики водоема переменной глубины. Модель описывает движение водного потока, термодинамику формирования и таяния льда, учитывает силу Кориолиса, горизонтальную и вертикальную турбулентность водной среды, сложную геометрию береговой линии и дна, трение о дно и ветровые течения, испарение, скорость ветра и плотность атмосферы, отклонение значения поля давления от гидростатического приближения. В работе проведено исследование влияния пространственного распределения температуры, солености, ионного состава и гидростатического давления на процессы формирования ледового покрова. В качестве объекта моделирования был выбран водоём (озеро) - Каспийское море. В качестве входных данных используются изменения распределений температуры и солености, измеренные по электропроводности воды с учетом ионного состава вод Каспийского моря за многолетний период. Моделирование движения водного потока позволят реагировать на техногенные угрозы в ускоренном режиме времени. Представленные в работе модели гидродинамики, могут быть адаптированы для других водоемов при использовании соответствующих геоинформационных систем.

Ключевые слова: Каспийское море, гидродинамические процессы, льдообразование, ионный состав, математическое моделирование

\section{Авторы:}

Леонтьев Антон Леонидович, Южный федеральный университет (344006, Ростов-на-Дону, ул. Большая Садовая, 105/42), аспирант, leontyev anton@mail.ru, ORCID: 0000-0002-0608-4343

Чумак Маргарита Игоревна, Донской государственный технический университет (344000, Ростов-на-Дону, пл. Гагарина, 1), магистрант, chumaaak1908@gmail.com

\footnotetext{
* Исследование выполнено при финансовой поддержке РФФИ в рамках научного проекта № 19-31-51017.
} 